Endocrinol. Japon. 1989, 36 (2), 219-228

\title{
Steroid Hormone Receptors in the Uterus and Ovary of Immature Rats Treated with Gonadotropins
}

\author{
Satoko ARAKAWA, Masato IYo, Ryo OHKAWA, Akira KaMBEGAWA \\ SHOICHI OKINAGA AND KIYOSHI ARAI
}

Department of Obstetrics and Gynecology, Teikyo University School of Medicine 2-11-1, Kaga Itabashi-ku, Tokyo, Japan

\begin{abstract}
We administered either saline (group A) or $10 \mathrm{IU}$ of pregnant mare serum gonadotropin (PMS; groups $\mathbf{B}$ and $\mathrm{C}$ ) to female immature rats. Fifty-three hours later, the rats were injected with saline (groups A and B) or $30 \mathrm{IU}$ of human chorionic gonadotropin (hCG; group $\mathrm{C}$ ). The rats were decapitated $17 \mathrm{~h}$ after the last treatment, and the serum levels of progesterone $\left(\mathrm{P}_{4}\right)$ and estradiol $\left(\mathrm{E}_{2}\right)$ were measured by specific radioimmunoassays (RIA). The receptor levels of progesterone (PR) and estrogen (ER) in the uterus and ovaries were measured and the dissociation constant (Kd) of PR was obtained.

The highest serum level of $P_{4}$ was found in group $C$ and that of $E_{2}$ in group B. Cytsol levels of PR and ER in the uterus and ovary of the group $B$ were the highest. It was indicated that the PMS treated-group (B), which had developing follicles in the ovary and the high serum level of $E_{2}$, showed the highest concentration of ER and PR in both the ovary and the uterus. In the PMS and hCG-treated group (C), the uterine and ovarian steroid receptors decreased probably because of the luteinization and the high serum level of $\mathbf{P}_{4}$. The Kd uterine PR value was less than that of ovarian PR.
\end{abstract}

It is well known that progestins and estrogens have stimulatory and inhibitory effects on the ovarian steroidogenesis (Wada et al., 1984; Welsh Jr. et al., 1983; Schreiber et al., 1980; Fortune and Hansel, 1979). These effects are partly exerted through ovarian steroid receptors (Schreiber et al., 1980). Many published data deal with rat ovarian steroid receptors (Schreiber and Hsueh, 1979; Schreiber and Erickson, 1979; Sakabe et al., 1983 ; Fujii-Hanamoto et al., 1985 ; Hamilton et al., 1977 ; Saiduddin and Zassenhaus, 1977; Saiduddin and Zas-

Received October 19, 1988 senhaus, 1978), but the effect of gonadotropins on immature rat ovarian vs. uterine receptors of steroid hormones still remains to be clarified.

\section{Materials and Methods}

\section{Chemicals}

All chemicals and reagents used were of analytical grade. $\left[17 \alpha\right.$-methyl $\left.{ }^{-3} \mathrm{H}\right]-\mathrm{R} 5020$ (86.3 $\mathrm{Ci} / \mathrm{mmol})$, and $\left[2,4,6,7^{-3} \mathrm{H}(\mathrm{N})\right]$-estradio1-17 $\beta\left(\mathrm{E}_{2}\right)$ $(96.4 \mathrm{Ci} / \mathrm{mmol})$ were purchased from New England Nuclear Corp. (Boston, MA, USA). Other non radioactive steroids were obtained from Sigma Chemical Company (St. Louis, MO, USA). 
Pregnant mare serum gonadotropin (PMS) and human chorionic gonadotropin (hCG) were the product of Teikoku Hormone Co. (Tokyo, Japan). Trasylol was obtained from Bayer Co. (Leverkusen, Germany).

\section{Animals}

Immature female rats (24 days old) of the Wistar-Imamichi strain were used. The rats were divided into three groups. At $0900 \mathrm{~h}$, saline (group A) or 10 IU of PMS (groups B and C) was injected subcutaneously (s.c.). Fiftythree hours later, saline (groups A and B) and 30 IU of hCG (group C) was injected s.c. Seventeen hours after the last treatment, the rats were decapitated and blood samples were collected. The ovaries and the uterus were dissected out, weighed and kept frozen at $-80^{\circ} \mathrm{C}$ until steroid receptors were assayed.

\section{Radioimmunoassay (RIA) of $\boldsymbol{P}_{4}$ and $\boldsymbol{E}_{2}$}

The blood sample was centrifuged at 3000 rpm for 20 min and serum was separated. For the RIA of progesterone $\left(P_{4}\right)$, the serum was extracted twice with three volumes of ether. For the RIA of $E_{2}$, the serum was extracted first with hexane to remove lipid, and then extracted with ether in a similar way to $P_{4}$. The antibodies to $E_{2}$ and $P_{4}$ were prepared in our laboratory; Japanese albino rabbits were immunized by injecting $\mathrm{E}_{2}$-6-carboxymethyloxime BSA or $\mathbf{P}_{4}-11 \alpha$-hemisuccinate to produce specific antisera. The values for cross reaction of the $\mathbf{P}_{4}$ antibody (diluted at 1:200,000) with $20 \alpha$-hydroxy $\mathbf{P}_{4}$ and $17 \alpha$-hydroxy $\mathbf{P}_{4}$ were 6.73 and $0.89 \%$, respectively (Yoshida et al., 1973). Those for the $\mathrm{E}_{2}$ antibody (diluted at $1: 30,000$ ) to estrone and estriol were 3.2 and $1.8 \%$, respectively (Makino, 1973).

\section{Steroid radio receptor assay $(R R A)$ \\ 1) Buffer}

The buffer for the RRA consisted of $10 \mathrm{mM}$ Tris, $1.5 \mathrm{mM}$ EDTA, $1 \mathrm{mM}$ dithiothreitol, $10 \%$ glycerol, $10 \mathrm{mM}$ sodium molybdate, and 500 $\mathrm{KIE} / \mathrm{ml}$ Trasylol. The $\mathrm{PH}$ of the buffer was 7.4 for the preparation of the cytosol fraction and 8.0 for the incubation.

\section{2) Preparation of the cytosol fraction}

The ovaries and uterus were homogenized in a Polytron homogenizer and centrifuged at $105,000 \mathrm{~g}$ for $70 \mathrm{~min}$ at $4^{\circ} \mathrm{C}$. The supernatant was treated with dextran coated charcoal (DCC) $\left(0.25 \%\right.$ Norit $\mathrm{A}$ and $0.025 \%$ dextran) at $0{ }^{\circ} \mathrm{C}$ for $10 \mathrm{~min}$. We used this cytosol fraction for the RRA. Protein in the cytosol fraction was measured by Bradford's method (Bradford, 1976). 3) RRA of progesterone receptor $(P R)$

${ }^{3} \mathrm{H}-\mathrm{R} 5020$ was used as a radioactive ligand for the assay of PR. To measure the quantity and the dissociation constant (Kd) of PR, the cytosol fraction was incubated with $0.125-8 \mathrm{nM}$ ${ }^{3} \mathrm{H}-\mathrm{R} 5020$ overnight at $0{ }^{\circ} \mathrm{C}$. With this condition we can measure the Bmax of total PR, not free $P R$, because the dissociation rate of uterine and ovarian PR is very high (Feil et al., 1972, Milgrom et al., 1972, Schreiber et al., 1979). To rule out non specific binding, a 100 fold excess of cold R5020 was added to the control incubation tubes. After the incubation, unbound ${ }^{3} \mathrm{H}-\mathrm{R} 5020$ was removed by DCC, and bound ${ }^{3} \mathrm{H}-\mathrm{R} 5020$ was counted in a liquid scintillation spectrometer (Aloka Model LSC-703). The data were analysed by Scatchard plot (Scathard, 1949), and the number of maximum binding sites (Bmax) and $\mathrm{Kd}$ were calculated. For the competition assay, the cytosol fraction was incubated with 2 or $8 \mathrm{nM}{ }^{3} \mathrm{H}-\mathrm{R} 5020$ and a 100 fold excess of various other steroids. This gives percent specific binding of ${ }^{3} \mathrm{H}-\mathrm{R} 5020$ to the cytosol fraction. 4) Assay of estrogen binding capacity

${ }^{3} \mathrm{H}-\mathrm{E}_{2}$ was used as a radioactive ligand for the assay of estrogen binding capacity. The cytosol fraction was incubated for $30 \mathrm{~min}$ at $37^{\circ} \mathrm{C}$ with $2-8 \mathrm{nM}{ }^{3} \mathrm{H}-\mathrm{E}_{2}$ in the presence or absence of a 100 fold excess of cold $E_{2}$. Counts of ${ }^{3} \mathrm{H}-\mathrm{E}_{2}$ specifically bound to the cytosol fraction were obtained. However, because there was insufficient material, Scatchard analysis could not be performed for $E_{2}$.

\section{Statistical analysis}

Statistical analyses of the results were made by Student's $t$-test, and a $P$ value of less than 0.05 was considered significant.

\section{Results}

\section{Weight of ovaries and uterus}

A pair of ovaries from groups A, B, and $C$ weighed (mean $\pm S E$ ) 21.0 \pm 4.61 , $63.1 \pm 12.11$, and $78.3 \pm 12.6 \mathrm{mg}$, respective1y. There were significant differences among the three groups $(p<0.001)$. The uteri 
from groups $\mathrm{A}, \mathrm{B}$, and $\mathrm{C}$ weighed (mean \pm SE) $61.1 \pm 14.1, \quad 154.0 \pm 24.9$, and 123.9 $\pm 17.6 \mathrm{mg}$, respectively. There were significant differences among the three groups $(\mathrm{p}<0.001)$.

\section{Serum $P_{4}$ and $\mathbb{E}_{2}$}

The serum $\mathrm{P}_{4}$ level for group $\mathrm{B}$ was higher than that for group $A$, but the difference was not significant (Fig. 1a). The $\mathrm{P}_{4}$ level for group $\mathrm{C}$ was significantly higher than that for groups A and B $(p<0.001$, $p<0.05)$. The serum $E_{2}$ level for group B was higher than that for group A $(p<$ 0.05 ; Fig. 1b).

Fig. 1a

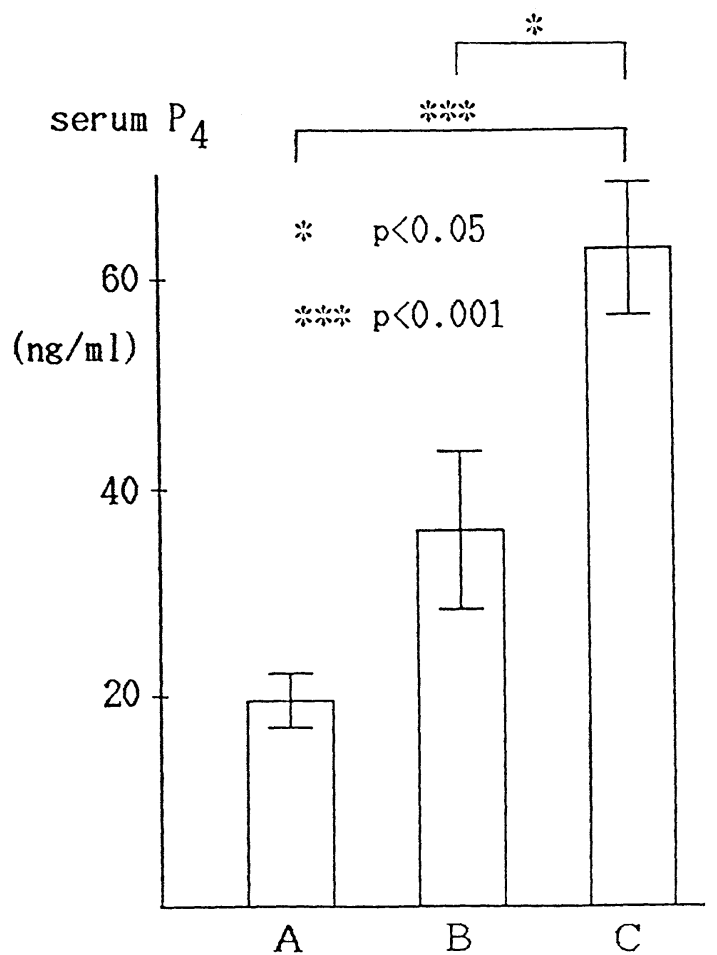

\section{$R R A$ of uterine and ovarian $P R$}

1) $K d$

The average $\mathrm{Kd}$ value for uterine $\mathrm{PR}$ was $0.315 \pm 0.080 \mathrm{nM}$, and that for ovarian PR was $3.37 \pm 1.53 \mathrm{nM}$. No significant difference in the $\mathrm{Kd}$ of the PR was observed among the group. The $\mathrm{Kd}$ value for ovarian PR was significantly higher than that for uterine PR $(p<0.001)$. Fig. 2 shows the Scatchard plot of equilibrium binding at $0^{\circ} \mathrm{C}$ of ${ }^{3} \mathrm{H}-\mathrm{R} 5020$ to the uterine and ovarian PR.

\section{2) Competition assay}

Fig. 3 shows specific binding of ${ }^{3} \mathrm{H}$ R5020 to PR in the ovaries and uterus as various competing steroids were added.

Fig. 1b

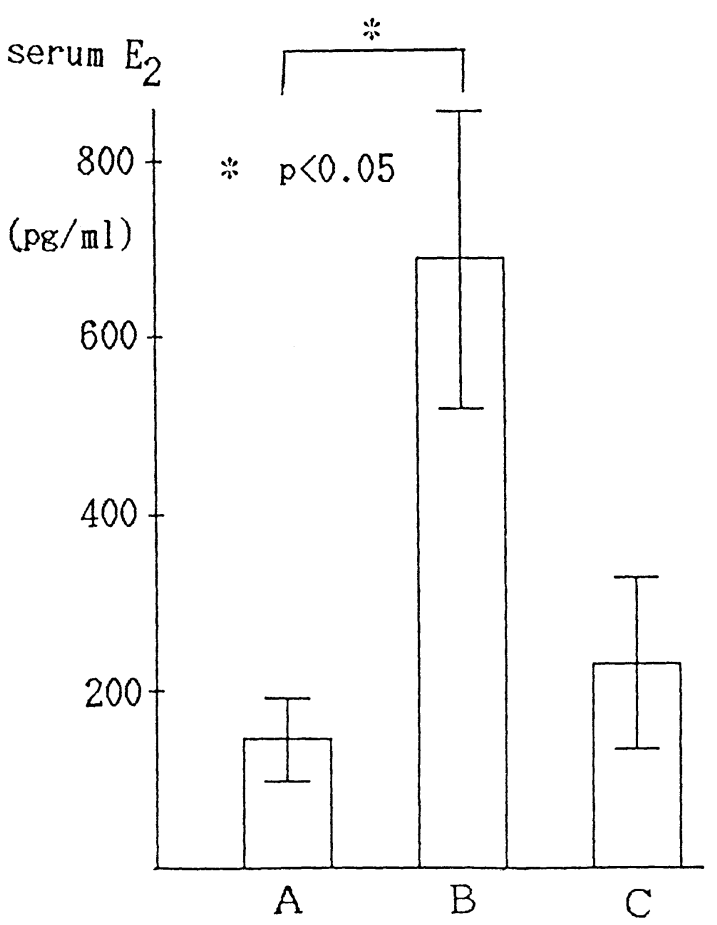

Fig. 1. Title: The serum level of (a) $P_{4}$ and (b) $E_{2}$ in the immature rat.

Legend: A : without gonadotropin treatment; B : treated with PMS ; C: treated with PMS and hCG. Vertical bars indicate standard errors. 
$\mathrm{E}_{2}$, dexamethasone (DEX), and testosterone (T) slightly interfered with the binding of ${ }^{3} \mathrm{H}-\mathrm{R} 5020$ to PRs. On the other hand, ${ }^{3} \mathrm{H}-\mathrm{R} 5020$ was effectively replaced with R5020 and $\mathrm{P}_{4}$ in ovarian and uterine PRs.

Fig. 2a Uterine PR

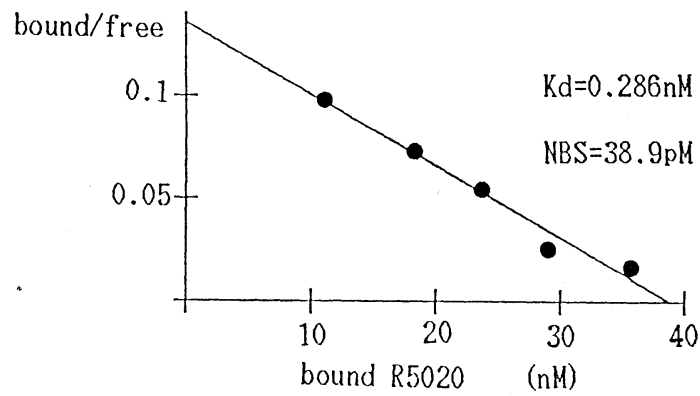

3) Number of maximum binding sites (Bmax) of $P R$

Fig. 4 shows the Bmax of cytosol PR in the uterus and ovary. The Bmax of PR in the uterus, as expressed per $\mathrm{mg}$ protein, of group A was significantly higher than

Fig. 2b Ovarian PR

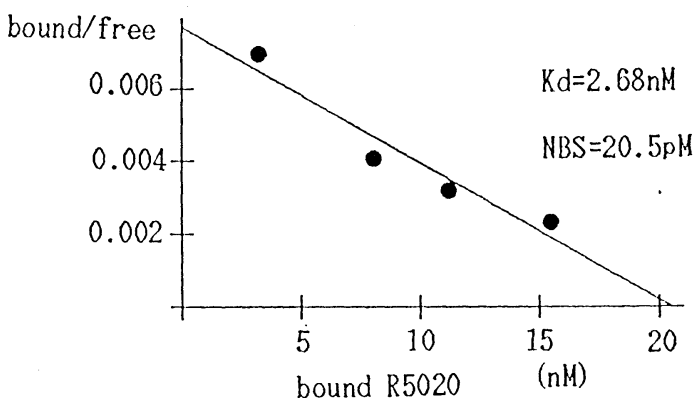

Fig. 2. Title: Scatchard plot of the uterine and ovarian PR.

Legend: (a) Uterine PR of the immature rat treated with PMS; (b) ovarian PR of the immature rat without gonadotropin treatment.

Fig. 3a Uterine PR

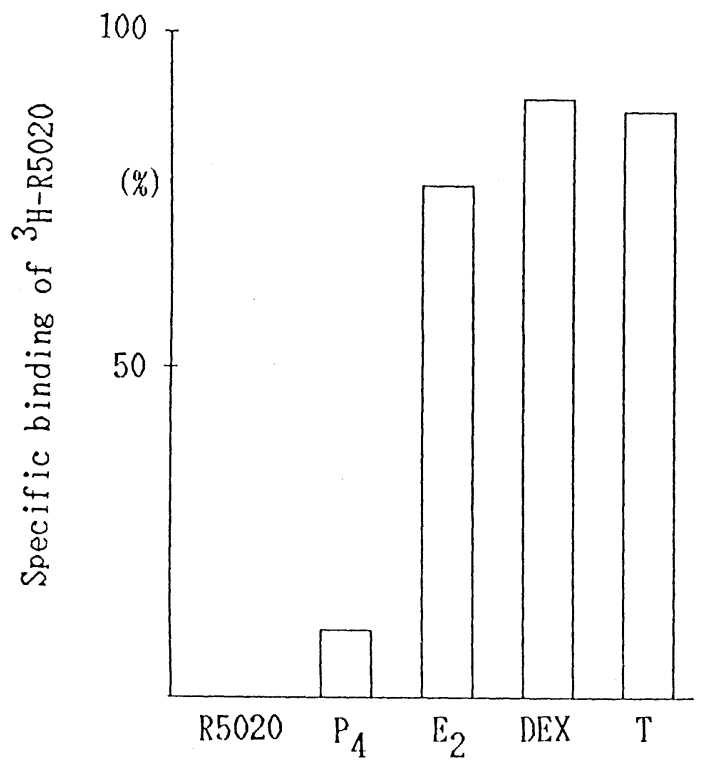

Fig. 3b Ovarian PR

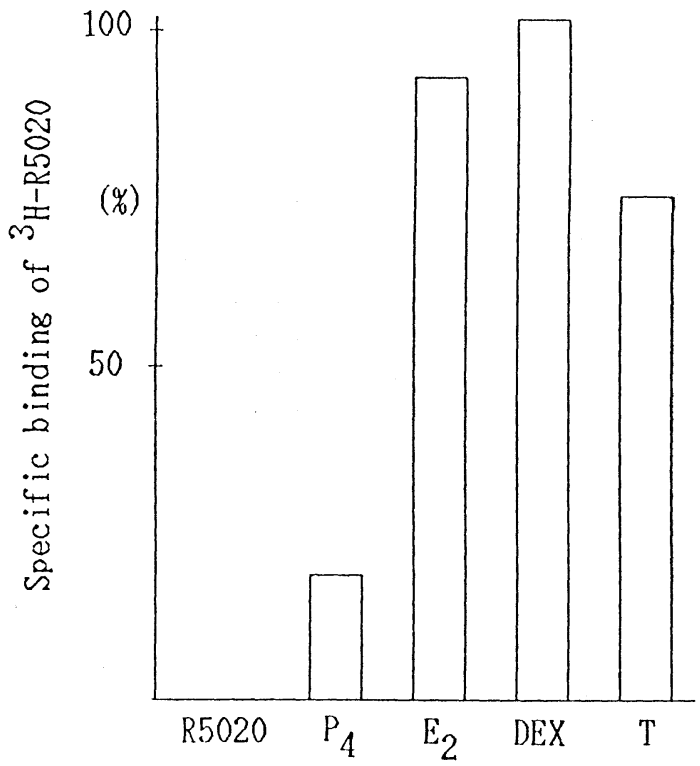

Fig. 3. Title: The competition assay of the (a) uterine and (b) ovarian PR.

Legend: The cytosol fraction was incubated with ${ }^{3} \mathrm{H}-\mathrm{R} 5020$ and 100 fold excess of other steroids. The Figures indicate percent specific binding of ${ }^{3} \mathrm{H}-\mathrm{R} 5020$ to the cytosol fraction compared to the control incubation with ${ }^{3} \mathrm{H}-\mathrm{R} 5020$ only. 
Fig. 4a Uterine PR
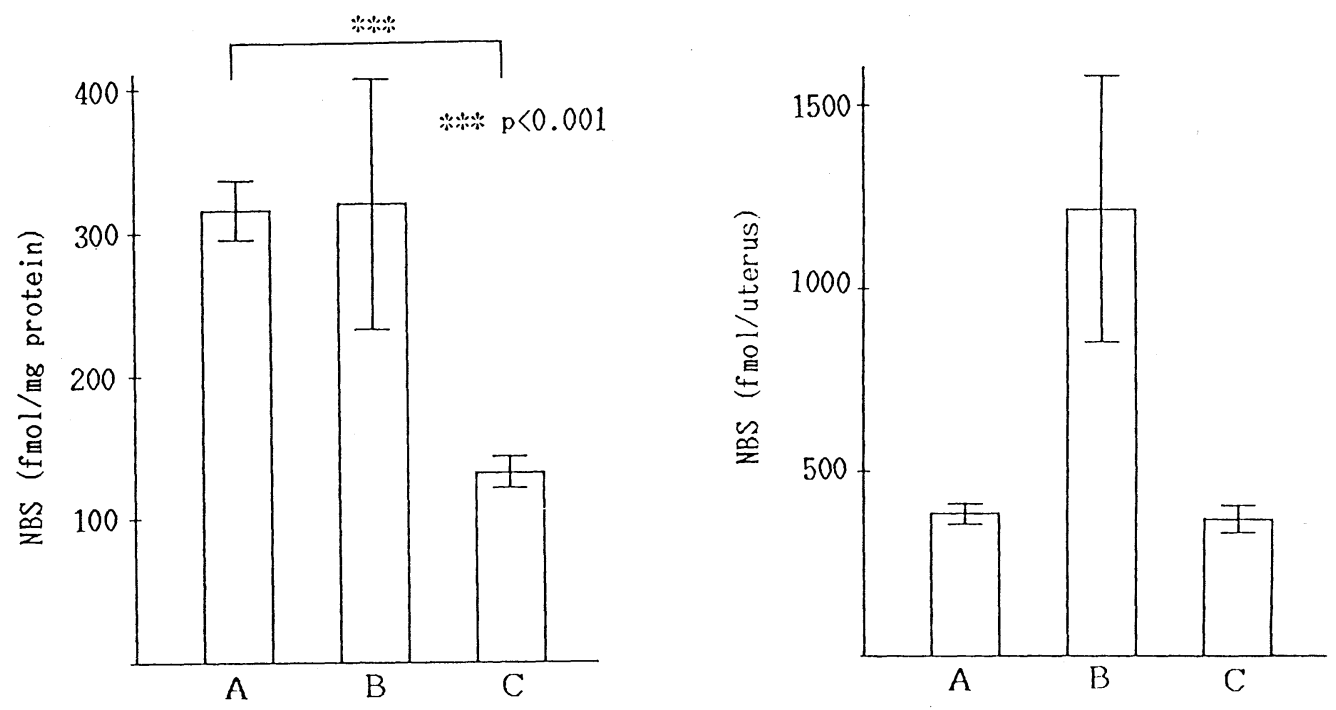

Fig. 4b Ovarian PR
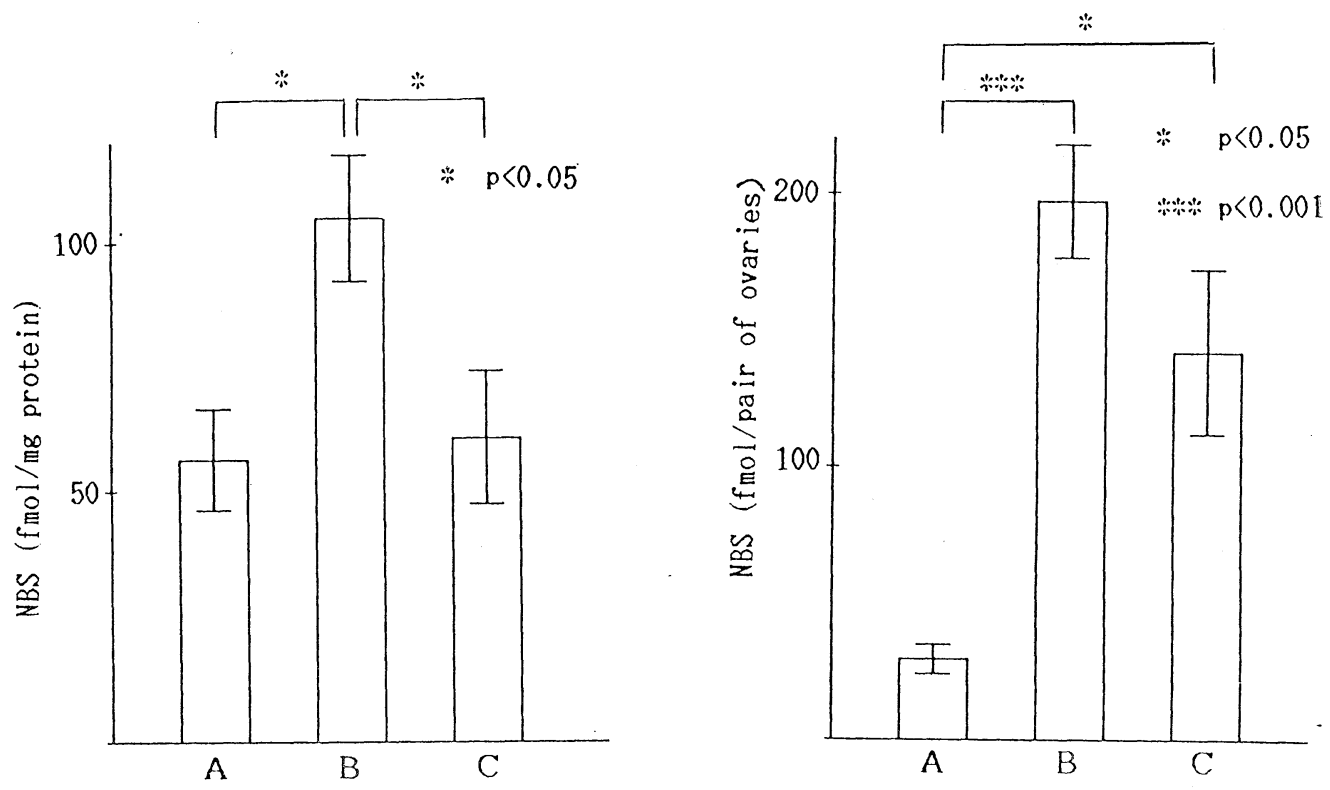

Fig. 4. Title: The Bmax of the (a) uterine and (b) the ovarian cytosol PR per unit weight of protein or per organ of the immature rat.

Legend: A: No gonadotropin treatment; B: Treated with PMS ; C: Treated with PMS and hCG. Vertical bars indicate standard errors. 
Fig. 5a $E_{2}$ bound to the uterus
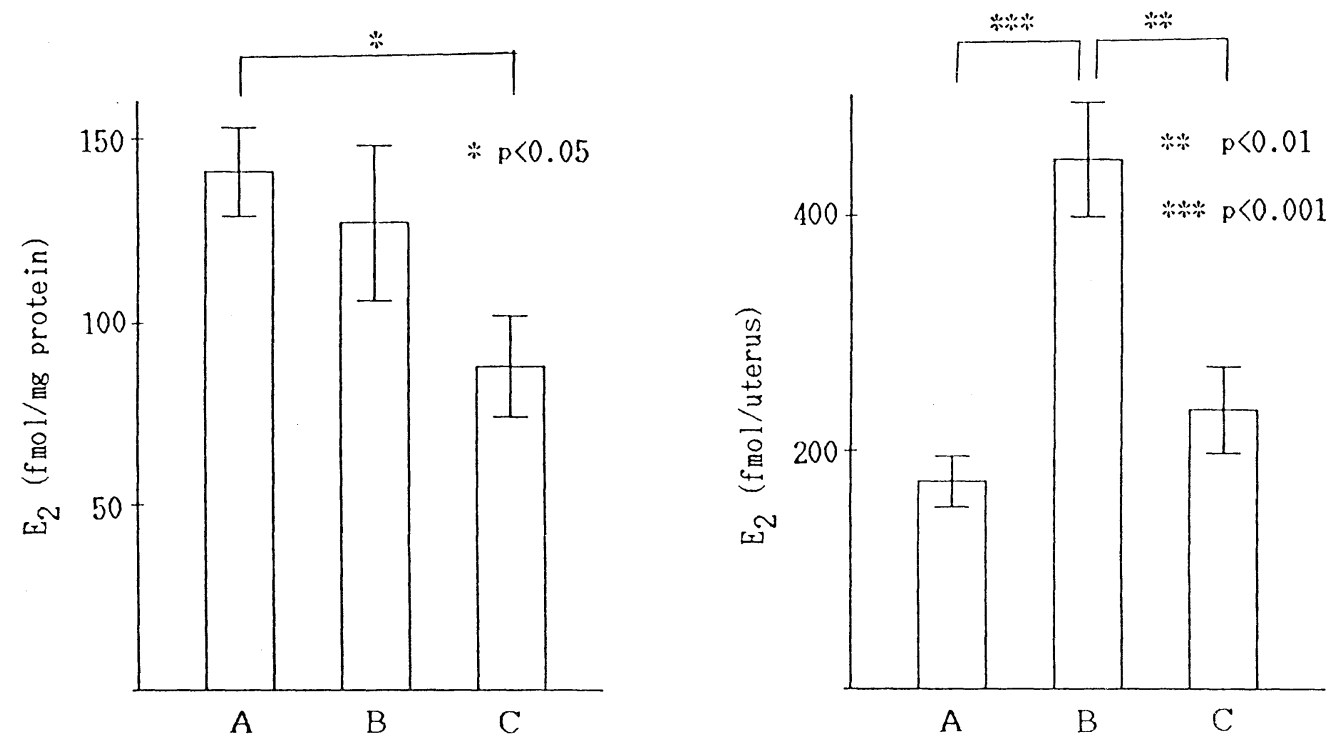

Fig. 5b $E_{2}$ bound to the ovaries
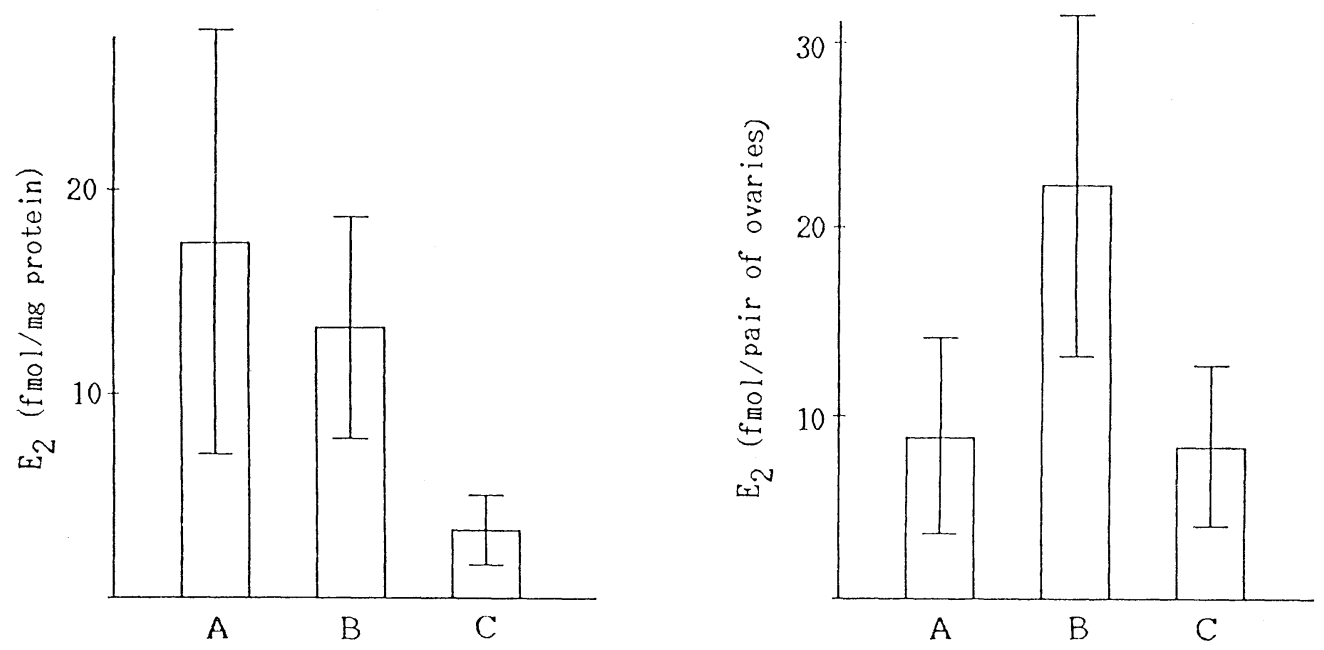

Fig. 5. Title: The bound ${ }^{3} \mathrm{H}-\mathrm{E}_{2}$ to the (a) uterine and (b) ovarian cytosol fraction per unit weight of protein or per organ of the immature rat.

Legend: A: No gonadotropin treatment; B: Treated with PMS; C: Treated with PMS and hCG. Vertical bars indicate standard errors. 
that of group C. When Bmax was expressed per uterus, group B showed the highest value. In the ovary, the Bmax of cytosol PR both per protein and per two ovaries of group B was significantly higher than that of group A $(p<0.05, p<0.001)$. The Bmax of PR per protein of group $C$ was significantly lower than that of group B $(\mathrm{p}<0.05)$.

\section{Assay of uterine and ovarian estrogen binding capacity}

Fig. 5 shows specific binding of $E_{2}$ to the cytosol fraction of the rat uterus and ovary. The total amount of ${ }^{3} \mathrm{H}-\mathrm{E}_{2}$ bound to the uterus of group B was significantly higher than that of the groups $\mathrm{A}$ and $\mathrm{C}$ $(p<0.001, p<0.01)$. In the ovary, there was no significant difference among three groups. However, the least binding of ${ }^{3} \mathrm{H}-\mathrm{E}_{2}$ to the ovarian preparation was observed in group C.

\section{Discussion}

The present study showed that the administration of PMS increased ovarian weight and the serum level of $E_{2}$. This indicates that the FSH component of PMS stimulates the development of the ovarian follicles, which secrete elevated levels of $\mathrm{E}_{2}$. The hCG administration after PMStreatment increased ovarian weight and the serum level of $\mathrm{P}_{4}$, but the serum level of $E_{2}$ decreased. This result indicates that hCG induces ovulation and the ovary is luteinized. The corpus luteum has high $3 \beta$-HSD activity and produces $\mathrm{P}_{4}$ in quantities. But the corpus luteum has less $17 \alpha$ hydroxylase and 17-20 lyase than the follicles, and consequently $E_{2}$ secretion decreases after luteinization (group C) (Suzuki and Tamaoki, 1979).

It is well known that $E_{2}$ increases uterine weight and $\mathbf{P}_{4}$ antagonizes this effect of $E_{2}$ (Jordan et al., 1978; Koseki et al., 1977).
In the present experiment, the heaviest uterine weight was found in group $\mathrm{B}$, which also showed the highest level of serum $E_{2}$. As the level of serum $\mathrm{P}_{4}$ reached the peak (group C), the serum level of $\mathrm{E}_{2}$ dropped and uterine weight decreased.

In our experiment, the $\mathrm{Kd}$ value for ovarian cytosol PR was greater than that of uterine PR. According to the reported data, the $\mathrm{Kd}$ value for the rat uterus is $1.1 \mathrm{nM}$ (Vu Hai and Milgrom, 1978), 0.29 nM (MacLusky and McEwen, 1980), 0.66 nM (Kirchhoff et al., 1983) or $2.22 \mathrm{nM}$ (Nagasaka, 1981) and that for the ovary is $14 \mathrm{nM}$ (Schreiber and Hsueh, 1979) or 22-4.8 nM (Fujii- Hanamoto, 1985). The values vary, but the $\mathrm{Kd}$ for ovarian PR is usually smaller than that for uterine PR. Further study will be needed to clarify the difference between the $\mathrm{Kd}$ values.

The number of maximum binding sites of uterine cytosol PR in group B was significantly larger than that in group $A$ or $C$, suggesting that $E_{2}$ increased uterine $P R$, and $\mathrm{P}_{4}$ antagonized this effect of $\mathrm{E}_{2}$ (Koseki et al., 1977; Miligrom et al., 1973). There is no report confirming that $\mathrm{E}_{2}$ increases ovarian PR. The present results revealed that group $B$, having the biggest number of mature follicles with granulosa cells, had the largest number for $\mathrm{PR}$; this agrees with previous findings that $P R$ is mainly located in granulosa cells (Schreiber and Erickson, 1979; Sakabe et al., 1983). On the other hand, the Bmax of PR in group $C$, which showed the highest level of serum $P_{4}$, was lower than that in group $B$ both in the uterus and ovary. The finding that ovarian PR is higher on the proestrous and diestrous days, and is lower on the metestrous and estrous days in cycling rats, suggests that folliculer development increases ovarian PR and luteinization decreases it (Sakabe et al., 1983; Fujii-Hanamoto et al., 1985).

If the $\mathrm{Kd}$ value for $\mathrm{ER}$ is constant, $\mathrm{E}_{2}$ binding capacity is parallel to the number of ERs. No evidence could be presented 
showing that the $\mathrm{Kd}$ value was constant in our experiments. Morris (Morris, 1976) reported that the $\mathrm{Kd}$ value for uterine ER of ovariectomized rat shortly after treatment with $\mathrm{E}_{2}$ was not constant, but this might be a special case because the $E_{2}$ administered would interrupt the RRA and increase the Kd value. Ginsburg (Ginsburg et al., 1975) reported that the $\mathrm{Kd}$ value for rat uterine ER was constant in the estrous cycle. The $\mathrm{Kd}$ value for the ER of pregnant rat corpus luteum was reported to be $0.22 \mathrm{nM}$ (Saiduddin et al., 1977) and that of immature rat was $0.413 \mathrm{nM}$ (Richards, 1974). These values are fairly close. It may be assumed that the $\mathrm{Kd}$ value was constant in our series of experiments and that largest number of ER were found in the group $B$ both in the uterus and ovary.

In the present series of experiments the maximal binding of $E_{2}$ to uterine and ovarian cytosol was seen in the group B among the three groups studied (Fig. 5). Although intrinsic $\mathrm{E}_{2}$ bound to $\mathrm{ER}$ could not completely be exchanged under the present experimental conditions, our results indicated that the $E_{2}$ binding capacity of group B was highest because the serum concentration of $\mathrm{E}_{2}$ was highest (Fig. 1); binding sites are also abundant.

It is reported that $E_{2}$ increases uterine ER, and $\mathrm{P}_{4}$ antagonizes this effect as in the case of the PR (Jordan et al., 1978; Okulicz et al., 1981; Bhakoo and Katzenellenbogen, 1977 ; West et al., 1978). In our experiments the number of uterine cytosol ER in group B was higher than that in groups $\mathrm{A}$ and $\mathrm{C}$ (as expressed per organ). Few reports compare the ovarian and uterine ER ; Saiduddin's experiments showed that $E_{2}$ increases, whereas $P_{4}$ decreases $E R$ in the uterus but not in the ovary (Saiduddin and Zassenhaus, 1978). Since the ovarian ER is mainly located in the granulosa cells (Stumpf, 1969; Richards, 1975), it is reasonable that group $\mathrm{B}$, in the present experiment, had more ER than the other 2 groups as expressed per organ. Because the level of serum $E_{2}$ was high in group $\mathrm{B}$, the "translocation" process might have been enhanced, and the number of cytosol ER in this group was maximum. It may be due to an increase in ER synthesis, the stability of ER or a change in the velocity of reactivation in the recycling system. Further study will be needed to clarify these points. In the present series of experiments, group $C$ had less ER than group $B$ in both the ovary and the uterus. The decrease in uterine ER may be due to the high level of serum $\mathrm{P}_{4}$ (Okulicz et al., 1981; Bhakoo and Katzenellenbogen et al., 1977; West et al., 1978), but in the case of the ovary it is also possible that the granulosa cells lost ER after luteinization; Richards (1975) reported that luteinization induced by $\mathrm{LH}$ decreased ovarian ER in the granulosa cells.

The number of steroid binding sites of the ovary may vary according to the serum concentration of the steroid. However, since the ovary is subjected to cyclic changes, such morphological variables may also have to be considered together with the serum concentration of steroids, when the binding capacity is discussed.

It may be concluded that PMS increased PR and ER in the uterus and ovary, and hCG decreased them in both tissues, suggesting that changes in PR and ER occurred concomitantly in the uterus and ovary under various endocrinological conditions.

\section{Acknowledements}

This work was partly supported by Grantin-Aid No. 63570799 for Scientific Research (C) in Japan. 


\section{References}

Bhakoo, H. S. and B. S. Katzenellenbogen (1977). Progesterone Modulation of Estrogen-Stimulated Uterine Biosynthetic Events and Estrogen Receptor Levels. Mol. Cel. Endocrinol. 8, 121-134.

Bradford, M. M. (1976). A Rapid and Sensitive Method for the Quantitation of Microgram Quantities of Protein Utilizing the Principles of Protein-Dye Binding. Analytical Biochemistry $72,248-254$.

Feil, P. D., S. R. Glasser, D. O. Toft and B. W. O'Malley (1972). Progesterone Binding in the Mouse and Rat Uterus. Endocrinology 91, 738-746.

Fortune, J. E. and W. Hansel (1979). The Effect of $17 \beta$-Estradiol on Progesterone Secretion by Bovine Theca and Granulosa Cells. Endocrinology 104, 1834-1838.

Fujii-Hanamoto, H., K. Seiki, K. Sakabe, Y. Haruki and H. Ogawa (1985). Progestin Receptors in Adult Rat Ovary during Estrous Cycle. Tokai J. Exp. Clin. Med. 10, 521-529.

Ginsburg, M., N. J. MacLusky, I. D. Morris and P. J. Thomas (1975). Phisiological variation in Abundance of Oestrogen Specific Highaffinity Binding Sites in Hypothalamus, Pituitary and Uterus of the Rat. J. Endocr. 64, 443-449.

Hamilton, T. C., P. Davies and K. Griffiths (1982). Oestrogen Receptor-like Binding in the Surface Germinal Epithelium of the Rat Ovary. J. Endocr. 95, 377-385.

Jordan, V. C., L. Rowsby, C. J. Dix and G. Prestwich (1978). Dose-Related Effects of NonSteroidal Antiestrogens and Oestrogens on the Measurement of Cytoplasmic Oestrogen Receptors in the Rat and Mouse Uterus. $J$. Endocr. 78, 71-81.

Kirchhoff, J., W. Grunke and R. Ghraf (1983). Estrogen Induction of Progestin Receptors in Pituitary, Hypothalamic and Uterine Cytoso1 of Androgenized Female Rats. Brain Res. 275, 173-177.

Koseki, K., D. T. Zava, G. C. Chamness and W. L. McGuire (1977). Progesterone Interaction with Estrogen and Antiestrogen in the Rat Uterus...Receptor Effects. Steroids 30, 169-177.

MacLusky, N. J. and B. S. McEwen (1980). Progestin Receptors in Rat Brain: Distribution and Properties of Cytoplasmic ProgestinBinding Sites. Endocrinology 106, 192-202.

Makino, T. (1973). Radioimmunoassay of sex steroid hormones. Folia Endocrinologica Japonica 49, 629-645 (in Japanese).

Miligrom, E., L. Thi, M. Atger and E E.. Baulieu (1973). Mechanism Regulating the Concentration and the Conformation of Progesterone Receptor(s) in the Uterus. J. Biol. Chem. 25, 6366-6374.

Miligrom, E., P. M. Atger and E. E. Baulieu (1972). Progesterone in Uterus and Plasma: V. An Assay of the Progesterone Cytosol Receptor of the Guinea Pig Uterus. Endocrinology 90, 1064-1070.

Morris, I. D. (1976). Change in Brain, Pituitary and Uterine Cytoplasmic Oestrogen Receptors Induced by Oestradiol-17 $\beta$ in the Ovariectomized Rat. J. Endocr. 71, 343-349.

Nagasaka, T. (1981). Change of Sex Steroid Hormone Receptors in Rat Uterine Cytosol during Experimental Induction of Endometrial Carcinoma. Acta Obst. Gynaec. Jpn. 33, 757766.

Okulicz, W. O., R. W. Evance and W. W. Leavitt (1981). Progesterone Regulation of Estrogen Receptor in the Rat Uterus: A Primary Inhibitory Influence on the Nuclear Fraction. Steroids 37, 463-470.

Richards, J. S. (1974). Estradiol Binding to Rat Corpora During Pregnancy. Endocrinology 95, 1046-1053.

Richards, J. S. (1975). Estradiol Receptor Content in Rat Granulosa Cells during Follicular Development: Modification by Estradiol and Gonadotropins. Endocrinology 97, 11741184.

Saiduddin, S. and H. P. Zassenhaus (1977). Estradiol-17 $\beta$ Receptors in the Immature Rat Ovary. Steroids 29, 197-213.

Saiduddin, S. and H. P. Zassenhaus (1978). Effect of Testosterone and Progesterone on the Estradiol Receptor in the Immature Rat Ovary. Endocrinology 102, 1069-1076.

Sakabe, K., K. Seiki, H. Fujii and Y. Haruki (1983). Progesterone Receptors in Ovaries of 4-day Cycling Rats. An Autoradiography Study. Tokai J. Exp. Clin. Med. 8, 187-192. Scatchard, G. (1949). The Attractions of Proteins for Small Molecules and Ions. Annals of the New York Academy of Science 51, 660672.

Schreiber, J. R., K. Nakamura and G. F. 
Erickson (1980). Progestins Inhibit FSH

Stimulated Steroidogenesis in Cultured Rat Granulosa Cells. Mol. Cel. Endocrinology 19, 165-173.

Schreiber, J. R. and A. J. W. Hsueh (1979). Progesterone "Receptor" in Rat Ovary. Endocrinology 105, 915-919.

Schreiber, J. R. and G. F. Erickson (1979). Progesterone Receptor in the Rat Ovary: Further Characterization and Localization in the Granulosa Cell. Steroids 34, 459-469.

Stumpf, W. E. (1969). Nuclear Concentration of ${ }^{3} \mathrm{H}$-estradiol in Target Tissues. Dry-Mount Autradiography of Vagina, Oviduct Ovary, Testis, Mammary Tumor, Liver and Adrenal. Endocrinology 85, 31-37.

Suzuki, K. and B. Tamaoki (1979). Enzymological Studies of Rat Luteinized Ovaries in Relation to Acute Reduction of Aromatizable Androgen Formation and Stimulated Production of Progestins. Endocrinology 104, 13171323.

Vu Hai, M. T and E. Milgrom (1978). Charac- terization and Assay of the Progesterone Receptor in Rat Uterine Cytosol. J. Endocr. 76, 21-31.

Wada, Y., A. Yajima, M. Suzuki and G. Greenwald (1984). In vitro Effects of Estradiol, Testosterone or Progesterone on Luteal Steroidogenesis in the Pregnant Rat. Endocrinol. Japon 31, 207-215.

Welsh, Jr. T. H., L. Zhuang, and A. J. W. Hsueh (1983). Estrogen Augmentation of Gonadotropin-Stimulated Progestin Biosynthesis in Cultured Rat Granulosa Cells. Endocrinology 112, 1916-1924.

West, N. B., R. L. Norman, B. A. Sandow and R. M. Brenner (1978). Hormonal Control of Nuclear Estradiol Receptor Content and the Luminal Epithelium in the Uterus of the Golden Hamster. Endocrinology 103, 17321741.

Yoshida, T., K. Den, H. Mukai, M. Noda, S. Takagi, T. Makino and A. Kambegawa (1973). Radioimmunoassay of sex steroid hormone (V). Hourumon to rinsho 21, 979-985 (in Japanese). 